\title{
XLVII. Remarks on Col. Miller's Plan for mooring ships in roadsteads
}

\author{
Mr. J.P. De la Fons
}

To cite this article: Mr. J.P. De la Fons (1827) XLVII. Remarks on Col. Miller's Plan for mooring ships in roadsteads, Philosophical Magazine Series 2, 2:10, 289-291, DOI: 10.1080/14786442708674389

To link to this article: http://dx.doi.org/10.1080/14786442708674389

里 Published online: 10 Jul 2009.

Submit your article to this journal $₫$

Џ Article views: 2

Q View related articles $\asymp$ 
green glass tube, still gave out arsenious acid, which sublimed and crystallized as in the former case; the quantity was however small, and the rest of the mineral fuzed at a red heat into a substance which, when cold, was brittle, gray, and by examination proved to consist of copper and arsenic, in combination with a small quantity of sulphur, and a trace of iron. I have no doubt that the gray metallic hard substance is an arseniuret of copper, but the difficulty of separating it perfectly from the accompanying bodies will interfere with an accurate determination of its composition.

XLVII. Remarks on Col. Miller's Plan for Mooring Ships in Roadsteads. By Mr. J. P. DE la Fons.

To the Editors of the Philosophical Magazine and Annals. Gentlemen,

BEING the patentee of a most material improvement in moorings, which invention is also applicable to other valuable purposes, I embrace as early an opportunity as occurs to me, for offering a few remarks upon a communication on the subject of moorings, which appeared in your Journal for August last.

That a mooring upon principles of perfect security is much wanted for the use of the merchant-service, no one acquainted with the subject can dispute. Whoever has witnessed the harrors of a shipwreck, which in the majority of cases originates in a defective anchorage must regret that nothing has yet been successfully attempted for the purpose of averting so frightful a calamity. In the hopes of attaining so desirable an object, various methods have been suggested, similar in principle to the one in question; some of which have been tried, but, as might be expected, they have failed at the very time when security was of the utmost importance. Nor can it be wondered at, when we consider that in lieu of the anchor, which, although it takes hold of the ground, is so liable to fail, a mass of iron depending upon its weight alone has been substituted, and with as probable a chance of success as if the aëronaut were to dispense with his grapples, and in the expectation of arresting its progress, attach his balloon to a weight that was inadequate to the resistance of so large a body driving before the wind.

Your correspondent's plan so far differs, that he proposes in some cases to fasten it, with pegs driven around it, into the ground by means of the diving-bell, which (the bell not being large enough to contain powerful machinery) I conclude he purposes doing by manual labour: but I apprehend any at-

New Series. Vol. 2. No. 10. Oct. 1827. $2 \mathrm{P}$ tempt 
tempt at securing it by such means must prove abortive, as nothing of sufficient strength could be driven with so limited a space to work in.

Mooring-blocks are likewise objectionable in shallows, as where a vessel draws much water she is liable to run foul of them, and thereby sustain considerable damage, -an evil that is avoided by making mooring-anchors with only one fluke.

The idea that the buoy would from its tendency upwards act as a spring upon the cable is incorrect, as the weight of the chain would reduce it to an equilibrium, unless it were made of an enormous size, so large as to endanger small craft that might come in contact with it.

There is an oversight in the method proposed for mooring the vessels, which, if secured to it in the way described (viz. by a strong hoop round the centre of the buoy), a very trifling strain, by elongating the hoop, would crush it nearly flat; but this error might easily be obviated by passing a bar through the buoy with the ring at the top for making fast to.

Having shown in the preceding observations that no anchorage can be relied on unless it take firm hold in the ground, it will be evident, and it has been admitted by every nautical man who has inspected it, that the safety mooring is constructed upon principles of perfect security, and that it could only fail by the breaking of the chain. The security of the mooring is effected by means of a pile strongly fastened to the mooringchain, which pile with the chain attached to be driven perpendicularly into the bed of the waters, at any station where it may be required. The piles should be about five or six diameters in length, and may be driven to the depth of several feet into the earth, according as the nature of the ground may require: this can be done at any anchorable depth, and without the aid of a diving-bell, by means of a newly-invented apparatus, which cannot be described without the assistance of drawings. The pile should be of a porous kind of wood, as when swoln by the absorption of moisture it would require immense perpendicular action to raise it, - a description of force to which it never would be subjected; - and being driven flush with the bottom, its stability could not possibly be affected by a vessel riding as she usually does at an angle of about thirty degrees.

Every practical man that has been consulted upon the subject, agrees, that if these permanent moorings were laid down in the roads, numbers of lives, as well as property to an immense amount, would be annually saved; as when a large ship drives, not only is she in danger, but as she bears down upon the others, they also to aroid the impending danger are com- 
pelled to slip their cables, until in like manner the evil has increased to an alarming extent,-a calamity that might henceforth be avoided, at an expense scarcely equal to the value of one richly freighted vessel. How many valuable India-men have been lost in sight of home, after escaping the perils of a long voyage, merely for the want of a security that can be afforded them at a comparatively trifling expense! Yours, \&c.

George-street, Hanover-square.

J. P. De la Fons.

XLVIII. On the Adhesion of Scretws. By B. Bevan, Esq., Civil Engineer.*

NEXT to that of nails, there are few things in more general use amongst artificers than screwes. I do not recollect seeing in any publication the results of any experiments on the force necessary to draw screws of iron, commonly called wood screws, out of given depths of wood. Having heretofore published the force necessary to extract nails driven into wood, the following results of my experiments on the force required to extract screws, made some time ago, may be of some interest.

The screws I used were about two inches in length, $\frac{22}{100}$ diameter at the exterior of the threads, $\frac{15}{10.0}$ diameter at the bottom, the depth of the worm or thread being $\frac{35}{10} 0$, and the number of threads in one inch $=12$. They were passed through pieces of wood, exactly half an inch in thickness, and drawn out by the weights specified in the following table:

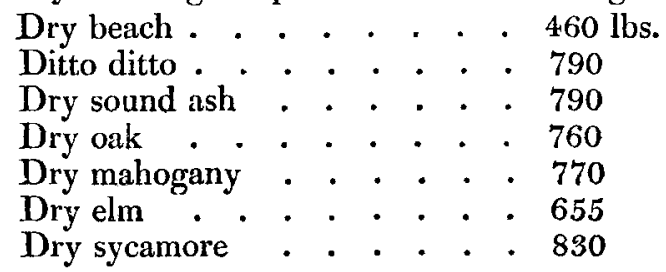

The weights were supported about two minutes before the screws were extracted.

I have also found the force required to draw similar screws out of deal and the softer wood about half the above.

From which we may infer, as a rule to estimate the full force of adhesion, in hard wood...200,000 dst=f, and in soft wood...100,000 $d \delta t=f$,

$d$ being the diameter of the screw ; $\delta$ the depth of the worm

* Communicated by the Author. 